\title{
INTERNATIONAL VARIATIONS IN APPLICATION OF THE BEST INTEREST STANDARD ACROSS THE AGE SPECTRUM
}

\author{
Naomi Laventhal, A.A. Eduard Verhagen, Thor Willy Ruud Hansen, Eugene Dempsey, \\ Peter G. Davis, Gabriel A. Musante, Alison Wiles, William Meadow, Annie Janvier
}

\section{Corresponding Author:}

Naomi Laventhal, MD, MA, FAAP

Affiliation:

Department of Pediatrics and Communicable Diseases

University of Michigan School of Medicine, Ann Arbor, MI

Address:

8-621 Mott C\&W Hospital

1540 E. Hospital Drive, SPC 4254

Ann Arbor, MI 48109-4254

USA

Phone: 734. 763. 4109/ Fax: 734 763. 7728

Email: naomilav@med.umich.edu

\section{Co-Authors:}

A.A. Eduard Verhagen, MD, JD, PhD

Department of Pediatrics, University Medical Center Groningen, University of Groningen, The Netherlands

Thor Willy Ruud Hansen, MD, PhD, MHA, FAAP

- Oslo University Hospital, Department of Neonatology, Division of Child and Adolescent, Clinical Ethics, Oslo, Norway

- University of Oslo, Institute of Clinical Medicine, Faculty of Medicine, Oslo, Norway

Eugene Dempsey, MD, MSc

INFANT Centre, Cork University Maternity Hospital, University College, Cork, Ireland

Peter G Davis, MD, FRACP

- $\quad$ The Royal Women's Hospital, Melbourne, Australia

- $\quad$ The University of Melbourne, Parkville, Victoria, 3010, Melbourne, Australia

\section{Gabriel A. Musante, MD, MSc}

Department of Maternal and Child Health

Hospital Universitario Austral - Universidad Austral, Buenos Aires, Argentina

\section{Alison Wiles, BS, MD candidate}

Rosalind Franklin University Chicago Medical School, Chicago, USA 


\section{William Meadow, MD, PhD}

Department of Pediatrics, University of Chicago, Chicago, USA

\section{Annie Janvier, MD, PhD}

University of Montreal, Monreal, Quebec, Canada

Department of Pediatrics

Department of Clinical ethics

CHU Sainte-Justine, Montreal, Quebec, Canada

Department of Neonatology

Clinical Ethics Unit

Running title: Variation in application of the best interest standard

Key words: Resuscitation, Ethics, Intensive Care, Neurodisability

Word Count: 2580 


\section{ABSTRACT:}

Objective: Ethically and legally, assertions that resuscitation is in a patient's best interest should be inversely correlated with willingness to forego intensive care (and accept comfort care) at the surrogate's request. Previous single country studies have demonstrated a relative devaluation of neonates when compared with other critically ill patients.

Study Design: In this international study, physicians in Argentina, Australia, Canada, Ireland, The Netherlands, Norway, and the United States were presented with 8 hypothetical vignettes of incompetent critically ill patients of different ages. They were asked to make assessments about best-interest, respect for surrogate autonomy and to rank the patients in a triage scenario.

Result: 2237 physicians responded (average response rate 61\%). In all countries and scenarios, participants did not accept to withhold resuscitation if they estimated it was in the patient's best interest, except for scenarios involving neonates. Young children (other than neonates) were given high priority for resuscitation, regardless of existing disability. For neonates, surrogate autonomy outweighed assessment of best interest. In all countries, a 2 month old infant with meningitis and a multiply disabled 7 year-old were resuscitated first in the triage scenario, with more variable ranking of the two neonates, which were ranked below patients with considerably worse prognosis.

Conclusion: The value placed on the life of newborns is less than that expected according to predicted clinical outcomes and current legal and ethical theory relative to best interests. Value assessments on the basis of age, disability, and prognosis appear to transcend culture, politics and religion in this domain. 


\section{INTRODUCTION}

Technological advances in medicine have led to higher survival rates of critically ill patients, but some patients survive with a compromised quality of life. Life-threatening conditions such as meningitis, trauma, or asphyxia can leave survivors with profound neurologic sequelae, and may lead to complex decision-making about continued medical care. The majority of neonatal and pediatric deaths, both within and outside of ICUs, generally follow withholding or withdrawing life-sustaining interventions ${ }^{1,2}$. Across the age spectrum, when critically ill patients are unable to participate in life-and-death decisions about their own care surrogate decision-makers are called upon to provide insights which inform physician’s management decisions.

Decision-making surrounding withholding or withdrawing life-saving interventions involves assessment of survival and outcome, a calculus which indirectly involves valuejudgments about the patient's life. Traditional legal and ethical teaching states that assessment of the patient's best interest should guide the care of incompetent patients ${ }^{3}$. The best interest standard calls upon surrogates to determine "the highest net benefit among available options," taking into account risks and benefits, quality-of-life considerations, and, for previously competent patients, their known personal preferences ${ }^{4}$. If an intervention is considered to be in the patient's best interest, and significant harm is caused by not intervening, refusal of treatment is generally not ethically or legally permissible.

In 2008, Janvier et al published a study demonstrating systematic devaluation of neonates during resuscitation decisions in comparison to older patients with worse prognoses ${ }^{5}$. Accepting a family’s refusal of resuscitation, even among participants who thought that resuscitation was in the patient's best interest, was much more common for newborns. Although 
this study demonstrated high response rates and internal validity, the external validity is unclear due to the predominately student participant cohort at a single university center. The purpose of this study was to evaluate how life and death decisions are made for incompetent patients in seven different countries using the same questionnaire. Specifically, we sought to describe whether the best interest principle was followed for resuscitation decisions in critically ill patients.

\section{METHODS}

The questionnaire was developed by Janvier ${ }^{5}$ and was translated, pilot tested, and administered to physicians in 7 different countries: Argentina, Australia, Canada, Ireland, The Netherlands, Norway, and the United States (U.S.). Results were collected and analyzed by individual investigators in each country; the studies in the U.S., Norway, Ireland, and Australia

were independently published ${ }^{6,7,8,9}$. Differences between countries in the survey instrument and data collection methods prohibit the analysis of these results as a single data set. Specifc sampling and survey methods by country are described in Table 1. Between-country differences in the survey instrument are described below.

The questionnaire detailed eight scenarios of currently incompetent, critically ill patients of different ages, all with potential neurologic sequelae. All arrived in the emergency department of a university health center without a surrogate decision-maker. Detailed descriptions of the vignettes are shown in Appendix 1. The specific probabilities for each patient's outcome are detailed in Table 2. We did not provide information on gender, marital, or socioeconomic status. Four of the hypothetical patients had a 50\% chance of survival: a 24-week gestation premature infant; a term neonate with a known brain malformation (arteriovenous malformation [AVM]); a 2-month-old with bacterial meningitis; and a 50-year-old after a motor vehicle collision (MVC). 
If these patients survived, 50\% would survive without impairment, $25 \%$ mildly or moderately impaired, and 25\% severely impaired. For the neonates, the vignettes assumed no previous opportunity for antenatal counseling.

Two other patients were already disabled: a 7 year-old with multiple neurologic and cognitive disabilities (including cerebral palsy [CP], deafness and learning disabilities) with new head trauma, and an 80 year-old with dementia and a new stroke. Both had a 50\% chance of predicted survival and, if they survived, a 50\% risk of further impairment.

Two patients had a 5\% chance of survival: a 14 year-old with acute myeloid leukemia (AML) and sepsis, with a 20\% risk of impairment, and a 35 year-old with brain cancer, with a 100\% risk of disability with invasive intervention (See Appendix 1).

Following each vignette, participants were asked the following questions:

- "Do you think that intubating, resuscitating, and consulting intensive care for admission is in the patient's best interest?"

- "If the parents/family asked you not to resuscitate, would you respect their decision?"

For each question, response options included: always, general, exceptionally, or never. Responses of "always" and "generally" were as analyzed as affirmative answers.

The surveys were quite similar in all countries, with small differences in wording of the survey questions based on country specific emergency care settings and phrasing of clinical presentation, without substantive differences in the scenarios. All countries reported the same prognoses in each vignette. Surveys for Argentina, The Netherlands, and Norway were translated into Spanish, Dutch, and Norwegian respectively. Norway administered the survey as part of a larger questionnaire and excluded the scenarios for the teenager and adult with cancer and a poor prognosis. Of note, although the original survey developed for the Canadian study used an age of 
14 years old for the teenage patient with AML, Australia, Ireland, The Netherlands, and The United States used an age of 13. Tables and figures present an age of 13 as this was used by the majority of countries.

Participants were also presented with a scenario in which all 8 patients arrived in the emergency department simultaneously. They were asked to rank the patients by resuscitation priority. Statistical evaluation for some of the previously published data can be found in the original publications ${ }^{6,7,8}$. For the ranking data, the average position for each of the eight vignettes was used. The study was approved by each institution's IRB where ethics review was required.

\section{RESULTS}

A total of 7,148 surveys were received by physicians in 7 countries; a total of 2,237 surveys are presented. The response rate by country ranged from $24 \%$ in Argentina to $78 \%$ in Australia. The majority of participants were physicians involved in the care of neonates. Additional demographic data are reported in Table 1.

\section{Best Interest}

Estimations of the best interest for the 8 patients are shown in Figure 1. The majority of participants considered resuscitation to be in the best interest of all the patients with a 50\% chance of survival except the 80-year-old patient. The 2-month-old infant and the 7-year-old child with multiple disabilities had the most participants stating that it was always or generally in the best interest of the patient to be resuscitated (over 90\% in every country), followed by the 50year-old patient where estimations of best interests were over $70 \%$ in all seven countries. The majority of participants in all countries felt that resuscitation was not in the best interest of the 80 
year-old. There was greater variability among responses to best interest question with the two patients with lower chance of survival (14 year-old AML/sepsis and 35 year-old/brain tumor). The affirmation of best interest for the patients with a 5\% probability of survival ranged from $42 \%$ in the US to $70 \%$ in Argentina.

\section{Best Interest vs. Accepting Non Resuscitation}

In all seven countries, four of the vignettes elicited the expected pattern: when resuscitation was estimated to be in the patient's best interest, requests to withhold it were not accepted (2 month-old, 7 year-old, 50 year-old), or conversely (80 year-old) (Figure 1). The one exception was The Netherlands, which favored autonomy over best interest for the 50 year-old.

In contrast, for the two neonates, although the majority of participants estimated that resuscitation would be in their best interest (except for The Netherlands), the majority would also accept requests to withhold resuscitation and give comfort care. Best-interest valuations greatly exceeded acceptance of non-resuscitation in Argentina compared to other countries (Figure 1).

\section{Triage Scenario}

In every country, participants would resuscitate the 2 month-old or the multiply disabled 7 year-old patient first or second, and the 80 year-old patient was consistently ranked last. The 3rd through 7th ranks varied greatly between countries (Table 3). The results from the Netherlands were the most incongruous; here the premature infant was ranked second to last, followed only by the 80 year-old.

\section{DISCUSSION}

This evaluation of how the best interest standard is applied for incompetent, critically ill patients across the age spectrum is the first to examine variations among physicians across 
multiple culturally different countries. When the initial iteration of this survey was published in 2008, many clinicians hypothesized that the apparent systematic devaluation of neonates was the result of cultural characteristics, the Canadian universal health care system, and limitation in sampling. We hypothesized that the results of this same questionnaire in culturally diverse countries would differ, but overall we found striking similarities in ethical decision-making. In fact, the results of these surveys are similar to those found among students of diverse academic disciplines ${ }^{5}$ and among physicians who care for patients across the age spectrum.

Legally and ethically, assertions that resuscitation is in the patient's best interest should be inversely correlated with willingness to forego resuscitation at the family's request. The majority of participants estimated that resuscitation was in all patients' best interests, except for the 80 year-old. For the elderly patient, few asserted that resuscitation was in this patient's best interest and the majority would accept a family's request for comfort care. For the 2 month-old with meningitis, the 7 year-old with multiple impairments and the 80 year-old with dementia and new stroke, the application of the best interest standard was applied similarly in all seven countries. For the two children, physicians favored prolongation of life, even over the parents' objections. However, for the two neonates, although the majority estimated resuscitation was in their best interest, the majority were also willing to provide comfort care at the family’s request.

The age of the patient appeared to be the strongest influence in the valuation of the patient's life, except for neonates. In the best-interest assessments and the triage scenario, the healthy 2 year-old with meningitis and the 7 year-old with pre-existing multiple disabilities were uniformly valued most highly. The 14 year-old with poor prognosis leukemia was ranked relatively highly in the triage scenario, despite having the same or worse prognosis as some of the older patients presented. Younger persons may be seen as having more potential and 
therefore "more to lose". This is also known to as the "fair innings" argument, in which health care resources should be distributed to "reduce inequalities in people's lifetime experience of health" ${ }^{10}$. However, our findings for the 2 newborn vignettes are inconsistent with this argument. Although the majority of participants were involved in the care of neonates, their answers were probably not guided by their clinical perspective. Indeed, the physicians in Norway who were not pediatricians provided similar answers, as did previous cohorts where participants were university students without medical background ${ }^{5}$. It seems the unique response to the neonatal vignettes transcends clinical specialty and profession.

The prognosis provided for all three of the infants (preterm, term and 2 month-old) was explicitly described and was the same, but we found striking differences in decision-making within this group. The 2 month-old with meningitis was consistently ranked first or second in the triage scenario, and participants followed the best interest standard for this scenario, but the two neonates were consistently ranked lower in the triage scenario - as low as $5^{\text {th }}$ or $7^{\text {th }}$ position in some countries and the majority accepted comfort care for them.

We have demonstrated systematic devaluation of neonates in a seven culturally diverse countries. There are a number of possible explanations for our findings. One is persistent bias against extremely preterm infants, despite advances in technology which have allowed improvements in the rates of mortality and morbidity in this population. The lack of personhood that is seemingly associated with premature babies could explain these findings ${ }^{5,11}$. Previous explanations of this devaluation have examined the concept of “saving” vs. “creating” a disabled life, which leads to differential decision-making for children with existing disabilities, as opposed to allowing the lives of neonates to begin and assuming responsibility for their disabilities ${ }^{12,13}$. This kind of bias is reinforced by existing policies and guidelines regarding the 
resuscitation of marginally viable neonates, which recommend careful and deliberate provision of prognostic information to expectant parents based on weeks of completed gestation and do not presume that resuscitation will occur ${ }^{14}$. Default options may be strong influencers of decisionmaking in the delivery room. ${ }^{15}$ In contrast, resuscitation of older children and older adults tends to be the default option and is not governed by institutional and organizational norms in the same way ${ }^{12,16}$.

Strikingly, in The Netherlands, the premature baby was ranked only higher than the 80 year-old patient with dementia and new brain injury. Although the Netherlands have levels of intervention similar for many pathologies, their policy statement for extremely preterm infants is non-interventionist compared to other countries ${ }^{17}$. Indeed, at the time of the survey, the policy statement informed neonatologists that intervention for a neonate born at 24 weeks was not indicated ${ }^{18}$. We speculate that policy statements may drive this anomalous finding, and may lead to a self-fulfilling prophecy.

Alternatively, an explanation for these findings is that participants simply did not accept the prognostic data we provided ${ }^{8}$. It is possible that participants did not read the outcome data we provided or did not believe the data for neonates. On the other hand, because the majority still estimated resuscitation was in their best interest, this is unlikely to be the only explanation.

Although our findings were similar in all countries, we did identify some interesting differences. In regards to the seemingly polarizing neonatal scenarios, physicians from Australia, Canada and the Netherlands tended to defer to family requests for non-resuscitation over bestinterest valuations, whereas those from Argentina and Ireland favored resuscitation. These variations between countries may represent systematic differences in cultural views of reproductive autonomy, access to and employment of pregnancy termination, and predominant 
religion. Differences in approach to systems for financing healthcare in these countries may also be relevant. Although substantive consideration of how these contextual features impacted our findings was not informed by our survey questions, these influences are worthy of further study employing additional research methods.

Physicians from the U.S. and Norway occupied an interesting position on the spectrum of decision-making. For the term infant with a brain vascular malformation, opinion appeared to be consistent with responses from Argentina and Ireland, favoring resuscitation over parental autonomy (although less dramatically). For the extremely preterm infant, U.S. and Norway physicians showed a more unique pattern of decision-making for our survey, in which nearly equal numbers supported both the best-interest assertion and deferral to the family about resuscitation. Again, this finding is thought-provoking, but our study design does not allow for its systematic analysis in the political, religious, economic, and cultural contexts of these countries.

These findings ${ }^{6,8}$ are similar to those noted in the Canadian cohort of students and trainees not included in this study ${ }^{5,11}$, supporting the claim that neonates, particularly those who are born extremely prematurely, represent a unique population when it comes to ethical decision making, in which traditional ethical principles break down and neither best-interest assessments nor parental autonomy prevail. Future work in this domain could further explore the complexed and nuanced values of expectant parents are considered by physicians, as these are increasingly emphasized in guidance for antenatal consultation ${ }^{19,20}$.

This study has limitations. Most importantly, variations in survey methods including modality, sampling frame, survey instrument, and population surveyed preclude analysis of these individual studies as a single data set, which would have allowed for additional statistical 
analyses and may have strengthened the significance and interpretability of the findings. These variations may also have been a significant factor affecting the response rates, which were quite variable. The responses we present are those for hypothetical scenarios; anticipated behaviors and decision-making might differ significantly from real life situations, and the discrepancy

between intent and behavior has been well described ${ }^{21}$. However, marked variation in the care of neonates has been demonstrated in the literature, suggesting that our findings may represent true decision-making patterns of physicians ${ }^{4,22}$.

Nonetheless, this paper presents a large cohort of survey responses from around North America, Europe, and Australia with surprisingly consistent findings in a number of domains, suggesting that for some bioethical questions, physician attitudes transcend the political, religious, and cultural climate of the country of origin.

\section{Conclusions}

Physicians in seven different countries do not consistently apply the best interest standard across the age spectrum. Age, prognosis, and previous disability all appear to influence medical decision-making and respect for surrogate autonomy. A unique pattern of ethical analysis appears to apply to preterm and term neonates, who are devalued compared to other vulnerable patients, independent of culture or country.

Conflict of Interest: The authors declare no conflict of interest. 


\section{Bibliography}

1. Fontana MS, Farrell C, Gauvin F, Lacroix J, Janvier A. Modes of death in pediatrics: differences in the ethical approach in neonatal and pediatric patients. J Pediatr 2013, 162(6): 1107-1111.

2. Verhagen A, Janvier A. THe continuing importance of how neonates die. JAMA Pediatrics 2013, 167(11): 987-988.

3. Leuthner SR. Decisions regarding resuscitation of the extremely premature infant and models of best interest. J Perinatol 2001, 21(3): 193-198.

4. Dupont-Thibodeau A, Barrington KJ, Farlow B, Janvier A. End-of-life decisions for extremely low-gestational-age infants: why simple rules for complicated decisions should be avoided. Seminars in perinatology 2014, 38(1): 31-37.

5. Janvier A, Leblanc I, Barrington KJ. Nobody likes premies: the relative value of patients' lives. J Perinatol 2008, 28(12): 821-826.

6. Hansen TW, Janvier A, Aasland O, Forde R. Ethics, choices, and decisions in acute medicine: a national survey of Norwegian physicians' attitudes. Pediatr Crit Care Med 2013, 14(2).

7. Armstrong K, Ryan CA, Hawkes CP, Janvier A, Dempsey EM. Life and death decisions for incompetent patients: determining best interests--the Irish perspective. Acta Paediatr 2011, 100(4): 519-523.

8. Laventhal N, Spelke MB, Andrews B, Larkin LK, Meadow W, Janvier A. Ethics of resuscitation at different stages of life: a survey of perinatal physicians. Pediatrics 2011, 127(5): 2010-1031.

9. Mills BA, Janvier A, Argus BM, Davis PG, Froisland DH. Attitudes of Australian neonatologists to resuscitation of extremely preterm infants. J Paediatr Child Health 2015, 51(9): 870-874.

10. Williams A. The rationing debate: Rationing health care by age: The case for, vol. 314, 1997.

11. Janvier A, Leblanc I, Barrington KJ. The best-interest standard is not applied for neonatal resuscitation decisions. Pediatrics 2008, 121(5): 963-969.

12. Janvier A, Mercurio MR. Saving vs creating: perceptions of intensive care at different ages and the potential for injustice. $J$ Perinatol 2013, 33(5): 333-335.

13. Janvier A, Barrington KJ, Aziz K, Lantos J. Ethics ain't easy: do we need simple rules for complicated ethical decisions? Acta Paediatr 2008, 97(4): 402-406. 
14. Hester DM. Interests and neonates: there is more to the story than we explicitly acknowledge. Theor Med Bioeth 2007, 28(5): 357-372.

15. Bello M, Becerril-Montekio VM. [The health system of Argentina]. Salud publica de Mexico 2011, 53 Suppl 2: s96-s108.

16. Janvier A, Bauer K, Lantos J. Are Newborns Morally Different from Older Children? Theor Med Bioeth 2007, 28(5): 413-425.

17. Pignotti MS, Donzelli G. Perinatal Care at the Threshold of Viability: An International Comparison of Practical Guidelines for the Treatment of Extremely Preterm Births. Pediatrics 2008, 121(1): e193-e198.

18. Verloove-Vanhorick SP. Management of the neonate at the limits of viability: the Dutch viewpoint. BJOG: An International Journal of Obstetrics \& Gynaecology 2006, 113: 1316.

19. Robertson J, Newby DA, Walkom EJ. Health Care Spending: Changes in the Perceptions of the Australian Public. PloS one 2016, 11(6): e0157312.

20. Zamberlin N, Romero M, Ramos S. Latin American women's experiences with medical abortion in settings where abortion is legally restricted. Reproductive health 2012, 9(1): 34.

21. Sheeran P. Intention-Behavior Relations: A Conceptual and Empirical Review. European Review of Social Psychology 2002, 12(1): 1-36.

22. Guevara-Aguirre J, Balasubramanian P, Guevara-Aguirre M, Wei M, Madia F, Cheng CW, et al. Growth Hormone Receptor Deficiency Is Associated with a Major Reduction in Pro-Aging Signaling, Cancer, and Diabetes in Humans. Science Translational Medicine 2011, 3(70): 70ra13. 
Figure 1: Is resuscitation in the best Interest of the patient vs. Would you agree to withhold resuscitation and give comfort care that the family's request? Percent Affirmative Responses Vignette and Country* (CP - cerebral palsy, MVC - motor vehicle collision, AML - acute myelogenous leukemia, C-spine - cervical spine) ** Norway did not present the two scenarios with a poor prognosis for survival (14 year-old, 35 year-old) 
Figure 1: Is resuscitation in the best Interest of the patient vs. Would you agree to withhold resuscitation and give comfort care that the family's request? Percent Affirmative Responses Vignette and Country* (CP - cerebral palsy, MVC - motor vehicle collision, AML - acute myelogenous leukemia, C-spine - cervical spine) ** Norway did not present the two scenarios with a poor prognosis for survival (14 year old, 35 year old)
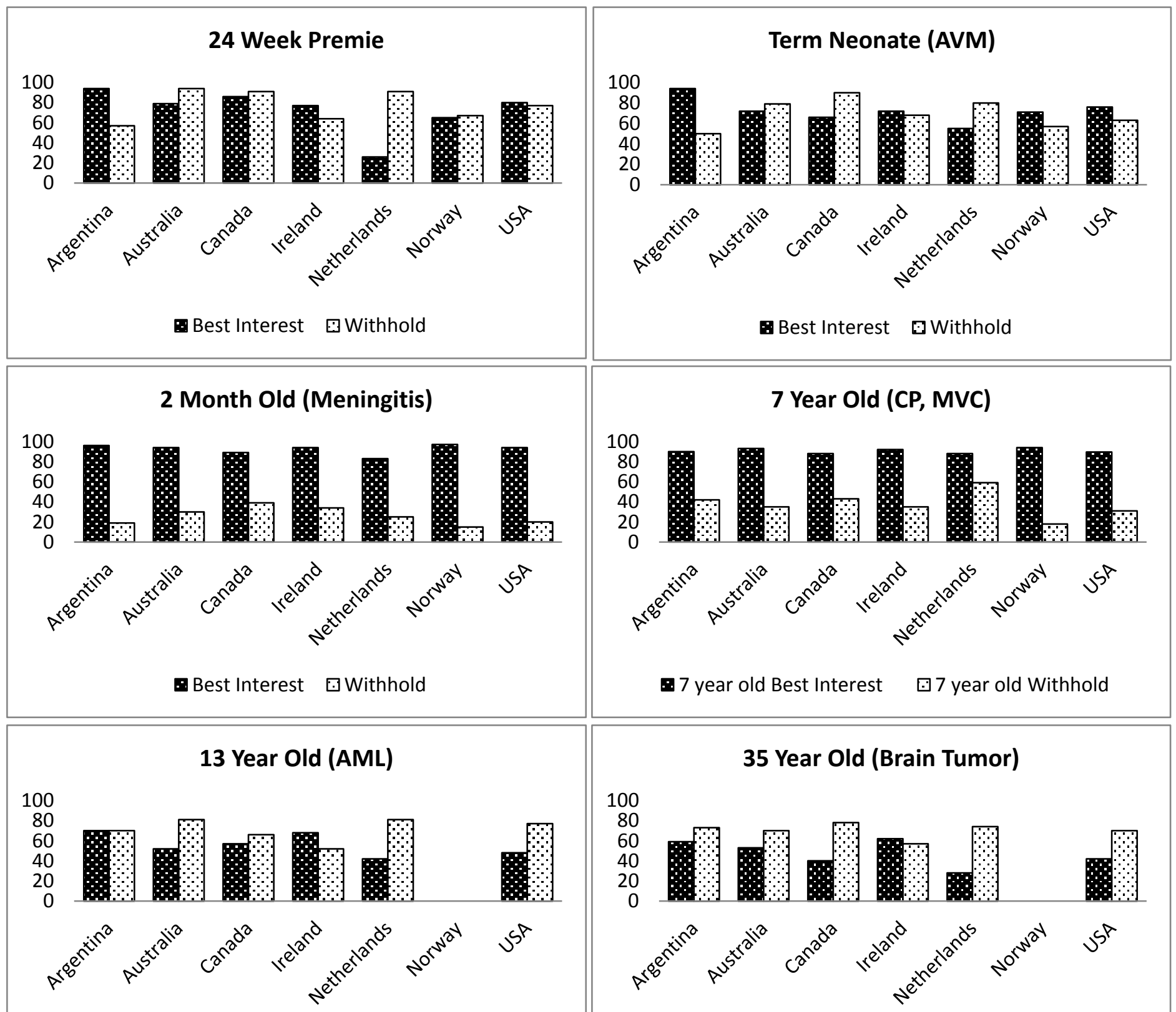

Best Interest $\square$ Withhold
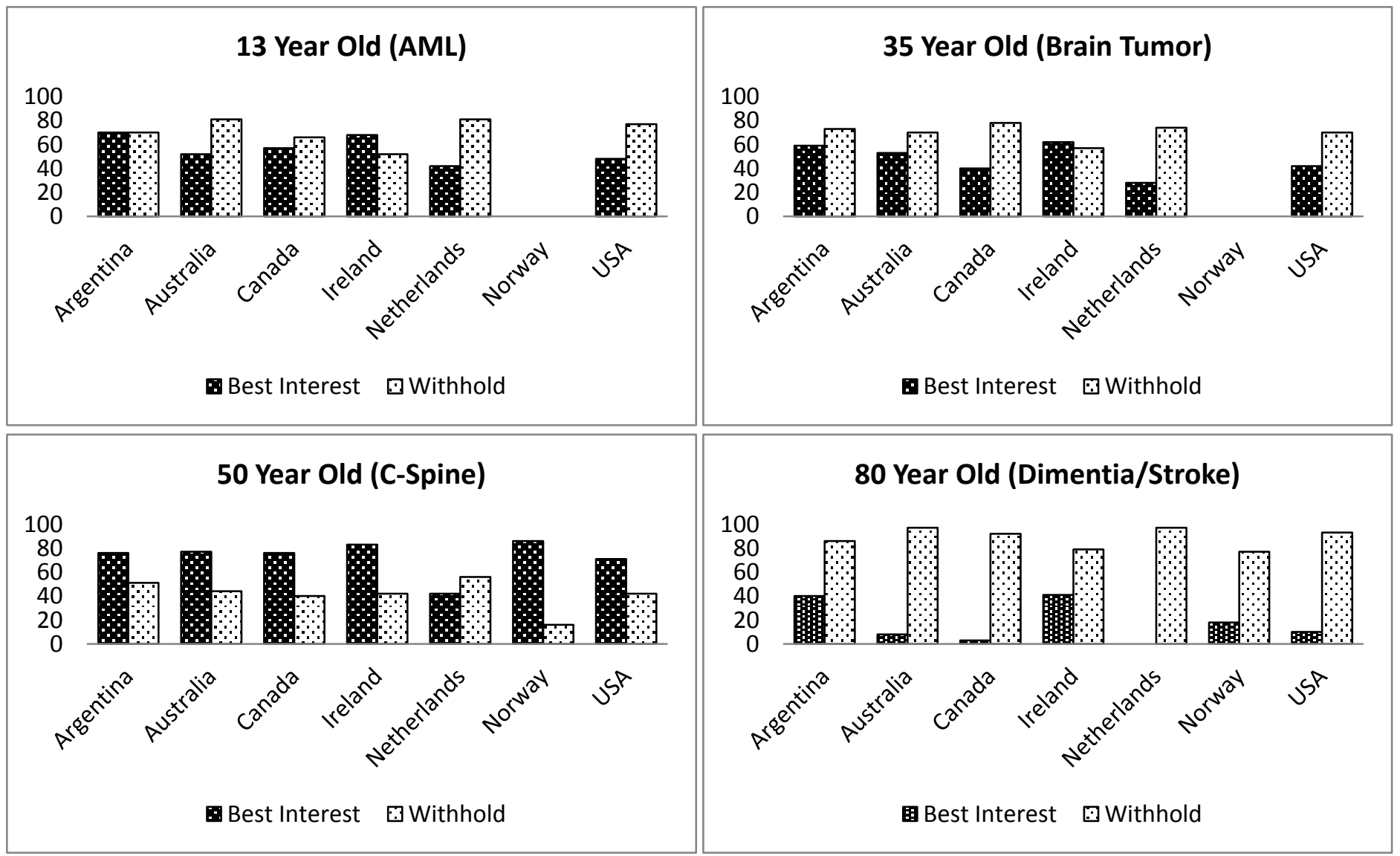
Table 1: A summary of survey methods and sampling frames in each country ${ }^{6,7,8}$

\begin{tabular}{|c|c|c|c|c|c|c|}
\hline $\begin{array}{l}\text { Country } \\
\text { (year) }\end{array}$ & Method & $\begin{array}{c}\text { Sampling Frame } \\
\text { (\% completed training) }\end{array}$ & $\begin{array}{c}\mathrm{N} \\
\text { participants/ } \\
\text { response } \\
\text { rate } \\
\end{array}$ & $\begin{array}{l}\text { Age or years in } \\
\text { practice }\end{array}$ & $\begin{array}{l}\text { \% } \\
\text { wome } \\
\text { n }\end{array}$ & $\begin{array}{l}\text { \% } \\
\text { with } \\
\text { child- } \\
\text { ren }\end{array}$ \\
\hline $\begin{array}{l}\text { Argentina } \\
(2008)\end{array}$ & Internet & $\begin{array}{l}\text { Convenience sample of } \\
\text { neonatologists in } \\
\text { Argentina (100\%) }\end{array}$ & 112 (24\%) & $\begin{array}{l}\text { Years in } \\
\text { practice: } \\
\text { Mean } 17.3 \\
\text { SD } 9.7\end{array}$ & $\begin{array}{l}\text { Not } \\
\text { asked }\end{array}$ & $\begin{array}{l}\text { Not } \\
\text { asked }\end{array}$ \\
\hline $\begin{array}{l}\text { Australia } \\
\text { (2009) }\end{array}$ & Internet & $\begin{array}{l}\text { All neonatologists } \\
(100 \%)\end{array}$ & 109 (78\%) & $\begin{array}{l}18 \% 30-39 \\
41 \% 40-49 \\
30 \% 50-59 \\
11 \%>60\end{array}$ & $37 \%$ & $\begin{array}{l}\text { Not } \\
\text { asked }\end{array}$ \\
\hline $\begin{array}{l}\text { Canada } \\
\text { (2008) }\end{array}$ & Mail & $\begin{array}{l}\text { All neonatologists } \\
(100 \%)\end{array}$ & $93(70 \%)$ & $\begin{array}{l}\text { Years in } \\
\text { practice: } \\
67 \%>5 \text { years }\end{array}$ & $47 \%$ & $86 \%$ \\
\hline $\begin{array}{l}\text { Ireland } \\
\text { (2009) }\end{array}$ & Mail & $\begin{array}{l}\text { Cork University } \\
\text { Hospital consultant and } \\
\text { non-consultant doctors } \\
\text { in neonatology, } \\
\text { pediatrics, obstetrics, } \\
\text { and emergency medicine } \\
(18 \%)\end{array}$ & $90(70 \%)$ & Not asked & $48 \%$ & $\begin{array}{l}\text { Not } \\
\text { asked }\end{array}$ \\
\hline $\begin{array}{l}\text { Nether- } \\
\text { lands } \\
\text { (2009) }\end{array}$ & Mail & All neonatologists (93\%) & $69(33 \%)$ & $\begin{array}{l}4 \% 25-30 \\
36 \% 30-36 \\
33 \% 40-49 \\
20 \% 50-59 \\
7 \%>60 \\
\end{array}$ & $63 \%$ & $67 \%$ \\
\hline $\begin{array}{l}\text { Norway } \\
\text { (2008) }\end{array}$ & Mail & $\begin{array}{l}\text { Random sampling } \\
(\mathrm{n}=1650) \text { of all members } \\
\text { of the Norwegian } \\
\text { Medical Association } \\
(\mathrm{n}=20225) \\
3.3 \% \text { pediatricians } \\
(100 \%)\end{array}$ & 1069 (66\%) & $\begin{array}{l}\text { Mean age } 48 \\
(47.3-48.795 \% \\
\text { CI) }\end{array}$ & $41 \%$ & $\begin{array}{l}\text { Not } \\
\text { asked }\end{array}$ \\
\hline $\begin{array}{l}\text { USA } \\
(2009)\end{array}$ & Internet & $\begin{array}{l}\text { All neonatologists and } \\
\text { high-risk obstetricians in } \\
\text { largest professional } \\
\text { societies } \\
85 \% \text { neonatologists } \\
(94 \%)\end{array}$ & $\begin{array}{l}695 \text { (16 \%) } \\
\text { (total } \\
\text { deployed } \\
\text { survey links) } \\
\text { (70\% of } \\
\text { opened links) }\end{array}$ & $\begin{array}{l}\text { Years in practice } \\
16 \%<5 \text { yrs } \\
13 \% 5-10 \text { yrs } \\
12 \% 10-15 \text { yrs } \\
15 \% 15-20 \text { yrs } \\
44 \%>20 \text { yrs }\end{array}$ & $40 \%$ & $84 \%$ \\
\hline
\end{tabular}


Table 2: Probability of Outcomes for Each of the 8 Patient Scenarios

\begin{tabular}{|l|l|l|l|}
\hline Description of Patient & $\begin{array}{l}\text { Probability of } \\
\text { survival }\end{array}$ & $\begin{array}{l}\text { Probability of } \\
\text { normal outcome } \\
\text { among Survivors }\end{array}$ & $\begin{array}{l}\text { Probability of new } \\
\text { significant } \\
\text { disability }\end{array}$ \\
\hline 24 week preterm infant & 50 & 50 & 25 \\
\hline $\begin{array}{l}\text { Term infant with } \\
\text { arteriovenous malformation }\end{array}$ & 50 & 50 & 25 \\
\hline $\begin{array}{l}2 \text { month old infant with } \\
\text { meningitis }\end{array}$ & 50 & 50 & 25 \\
\hline $\begin{array}{l}\text { 7 year-old child with cerebral } \\
\text { palsy, status post MVC* }\end{array}$ & 50 & 0 & 50 \\
\hline $\begin{array}{l}\text { 14 year-old with aggressive } \\
\text { leukemia }\end{array}$ & 5 & 80 & 20 \\
\hline $\begin{array}{l}35 \text { year-old with aggressive } \\
\text { brain tumor }\end{array}$ & 5 & 0 & 100 \\
\hline $\begin{array}{l}\text { 50 year-old status post MVC } \\
\text { with cervical spine injury }\end{array}$ & 50 & 50 & 25 \\
\hline $\begin{array}{l}\text { 80 year-old with dementia, } \\
\text { new stroke }\end{array}$ & 50 & 0 & 50 \\
\hline
\end{tabular}

* Motor-vehicle collision 
Table 3: Summary of ranking data in triage scenario by country*

\begin{tabular}{|c|c|c|c|c|c|c|c|}
\hline Ranking & $\begin{array}{c}\text { Argen- } \\
\text { tina }\end{array}$ & Australia & Canada & Ireland & $\begin{array}{l}\text { Nether- } \\
\text { lands }\end{array}$ & Norway & USA \\
\hline 1 & $\begin{array}{l}\text { 2-month- } \\
\text { old }\end{array}$ & $\begin{array}{l}\text { 2-month- } \\
\text { old }\end{array}$ & $\begin{array}{l}\text { 2-month- } \\
\text { old }\end{array}$ & 7-year-old & $\begin{array}{l}\text { 2-month- } \\
\text { old }\end{array}$ & 7-year-old & $\begin{array}{l}\text { 2-month- } \\
\text { old }\end{array}$ \\
\hline 2 & 7-year-old & 7-year-old & 7-year-old & $\begin{array}{l}\text { 2-month- } \\
\text { old }\end{array}$ & 7-year-old & $\begin{array}{l}\text { 2-month- } \\
\text { old }\end{array}$ & 7-year-old \\
\hline 3 & $\begin{array}{l}\text { Premature } \\
\text { Infant ( } 24 \\
\text { week GA) }\end{array}$ & $\begin{array}{l}\text { Premature } \\
\text { Infant ( } 24 \\
\text { week GA) }\end{array}$ & $\begin{array}{l}\text { Premature } \\
\text { Infant ( } 24 \\
\text { week GA) }\end{array}$ & $\begin{array}{l}\text { Term } \\
\text { Infant }\end{array}$ & $\begin{array}{l}\text { Term } \\
\text { Infant }\end{array}$ & $\begin{array}{l}\text { 50-year- } \\
\text { old }\end{array}$ & \multirow{2}{*}{$\begin{array}{c}\text { Premature } \\
\text { Infant (24 } \\
\text { week GA) } \\
\text { \& Term } \\
\text { Infant }\end{array}$} \\
\hline 4 & $\begin{array}{l}\text { Term } \\
\text { Infant }\end{array}$ & $\begin{array}{l}\text { Term } \\
\text { Infant }\end{array}$ & $\begin{array}{l}\text { 14-year- } \\
\text { old }\end{array}$ & $\begin{array}{l}\text { 14-year- } \\
\text { old }\end{array}$ & $\begin{array}{l}\text { 14-year- } \\
\text { old }\end{array}$ & $\begin{array}{l}\text { Term } \\
\text { Infant }\end{array}$ & \\
\hline 5 & $\begin{array}{l}\text { 14-year- } \\
\text { old }\end{array}$ & \multirow[t]{2}{*}{$\begin{array}{c}\text { 14-year- } \\
\text { old \& 50- } \\
\text { year-old }\end{array}$} & $\begin{array}{l}\text { Term } \\
\text { Infant }\end{array}$ & \multirow{2}{*}{$\begin{array}{c}\text { Premature } \\
\text { Infant (24 } \\
\text { week GA) } \\
\& 50- \\
\text { year-old }\end{array}$} & $\begin{array}{l}\text { 35-year- } \\
\text { old }\end{array}$ & $\begin{array}{l}\text { Premature } \\
\text { Infant (24 } \\
\text { week GA) }\end{array}$ & $\begin{array}{l}\text { 14-year- } \\
\text { old }\end{array}$ \\
\hline 6 & $\begin{array}{l}\text { 50-year- } \\
\text { old }\end{array}$ & & $\begin{array}{l}\text { 50-year- } \\
\text { old }\end{array}$ & & $\begin{array}{l}\text { 50-year- } \\
\text { old }\end{array}$ & & $\begin{array}{l}\text { 50-year- } \\
\text { old }\end{array}$ \\
\hline 7 & $\begin{array}{l}\text { 35-year- } \\
\text { old }\end{array}$ & $\begin{array}{l}\text { 35-year- } \\
\text { old }\end{array}$ & $\begin{array}{l}\text { 35-year- } \\
\text { old }\end{array}$ & $\begin{array}{l}\text { 35-year- } \\
\text { old }\end{array}$ & $\begin{array}{l}\text { Premature } \\
\text { Infant (24 } \\
\text { week GA) }\end{array}$ & & $\begin{array}{l}\text { 35-year- } \\
\text { old }\end{array}$ \\
\hline 8 & $\begin{array}{l}\text { 80-year- } \\
\text { old }\end{array}$ & $\begin{array}{l}\text { 80-year- } \\
\text { old }\end{array}$ & $\begin{array}{l}\text { 80-year- } \\
\text { old }\end{array}$ & $\begin{array}{l}\text { 80-year- } \\
\text { old }\end{array}$ & $\begin{array}{l}\text { 80-year- } \\
\text { old }\end{array}$ & $\begin{array}{l}\text { 80-year- } \\
\text { old }\end{array}$ & $\begin{array}{l}\text { 80-year- } \\
\text { old }\end{array}$ \\
\hline
\end{tabular}

* Norway did not present the two scenarios with a poor prognosis for survival (14 year-old, 35 year-old) 